\title{
Comparative Study of Helicoverpa armigera (Hubner) (Lepidoptera: Noctuidae) Preference for Bt and Non-Bt Soybean Cultivars
}

\author{
Vilmar Bueno Dos Santos', Luciana Barboza Silva1, Eliane Carneiro' ${ }^{*}$, Alexandre Faria Silva1, \\ Gleidyane Novais Lopes¹, Bruno Ettore Pavan², Thiago Ferreira Rodrigues ${ }^{1}$ \\ ${ }^{1}$ Postgraduate Program in Plant Science Agronomy, Universidade Federal do Piauí (UFPI), Bom Jesus, Piauí \\ ${ }^{2}$ FacultyofEngineering UNESP Ilha Solteira, Universidade Estadual Paulista, Ilha Solteira, Brasil \\ Email: *elian.cbs@hotmail.com
}

How to cite this paper: Santos, V.B., Silva, L.B., Carneiro, E., Silva, A.F., Lopes, G.N., Pavan, B.E. and Rodrigues, T.F. (2017) Comparative Study of Helicoverpa armigera (Hubner) (Lepidoptera: Noctuidae) Preference for Bt and Non-Bt Soybean Cultivars. American Journal of Plant Sciences, 8, 2483-2500. https://doi.org/10.4236/ajps.2017.810169

Received: July 21, 2017

Accepted: September 17, 2017

Published: September 20, 2017

Copyright $\odot 2017$ by authors and Scientific Research Publishing Inc. This work is licensed under the Creative Commons Attribution International License (CC BY 4.0).

http://creativecommons.org/licenses/by/4.0/

\begin{abstract}
Studies on the behavior of Helicoverpa armigera in relation to soybean cultivars expressing Bt proteins are fundamentally important for IPM. We determine the no-choice and feeding choice of $H$. armigera, the no-choice and oviposition choice in different $\mathrm{Bt}$ and non-Bt soybeans cultivars. In the first step it was carried out the experiment to determine the no-choice and food choice in test for $12 \mathrm{Bt}$ and non-Bt soybean cultivars. Simultaneously the consumption was determined. In a second step it was evaluated the no-choice and oviposition choice in different soybean cultivars. Helicoverpa armigera caterpillars showed neither attractiveness and preference for food nor attractiveness and oviposition preference for Bt and non-Bt soybean leaves when simultaneously contrasting the tested cultivars. This study showed that Bt toxin did not influence the oviposition preference, and $H$. armigera adults did not differentiate Bt and non-Bt soybean cultivars for oviposition indicating no behavioral preference. Third instar caterpillars showed no discrimination between $\mathrm{Bt}$ and non-Bt soybean leaves. Research in this area must focus on the possibility of widespread planting of genetically modified soybeans containing the Bt protein, which is associated with selection pressure and the behavior of pest species in relation to their hosts, as well as on the adequacy of management tactics that is able to prevent the loss of technology efficiency.
\end{abstract}

\section{Keywords}

Cry1Ac Protein, Genetically Modified Plants, Food Preference, Oviposition

\section{Introduction}

Helicoverpa armigera (Hubner) (Lepidoptera: Noctuidae) causes serious economic 
losses to crops such as soybeans corn, cotton, beans and sorghum, whit caterpillars feed on leaves, flowers, pods and grains [1]. Helicoverpa armigera control in almost every crop systems is carried out basically by insecticide spraying [2] [3]. Therefore, populations of this species are under strong selection pressure and resistance to the main chemical groups [4] [5] [6].

Breeders worldwide have focused on identifying soybean cultivars with insect resistance. The resistance mechanisms involved are basically antibiosis and antixenosis with negative effects on insect biology and behavior respectively [7] [8] [9].

Antibiosis is a resistance mechanism in plants. In this mechanism, the mortality rate of insects increases or larval growth and development decreases after insect feeding. By contrast, antixenosis is a resistance mechanism in which the insects are not attracted to the plant. Defoliator resistance in soybean may rely on one or both of these mechanisms [10] [11] [12] [13] [14].

Bacillus thuringiensis can also serve as a source of toxic genes that can be expressed in plants and thus confer toxic property against different species of insect pests. Genetically modified plants (GMPs) that express the Bt genes, such as rice, corn, potato, cotton, and soybean are associated with the control of pests, especially Lepidoptera. The resistant cultivars result in increased productivity, greater economic value, reduction in the use of chemical pesticides, and benefits in the selectivity of the target pest [15] [16].

However, the intensive use of Bt soybean has increased the likelihood of insects developing resistance to Bt-based bioinsecticides and transgenic plants [17]. Considering the little information about the effect of these resistant genotypes against $H$. armigera, information about the behavior of this pest species in relation to soybean cultivars expressing Bt proteins is fundamental for the IPM. Thus, the objective was to determine the attractiveness and the feeding and oviposition preference of $H$. armigera caterpillars for Bt and non-Bt soybeans cultivars.

\section{Material and Methods}

\subsection{Insects}

Populations of $H$. armigera used in the experiments were obtained from the institution stock, kept in artificial diet adapted [18] made with beans (500 g), wheat germ (237 g), beer yeast (152 g), ascorbic acid (15 g), sorbic acid (4.45 g), nipagin (9.45 g), Agar-agar (62 g), formaldehyde (12.45 ml), inhibitor solution (12.5 g) (propionic acid $41.8 \% 4.2 \%$ fosphoric acid and $54 \%$ water). Neonate caterpillars ( $<24$ hours old) were individualized and transferred to $100 \mathrm{ml}$ plastic containers with lid containing artificial diet until they reached the pupal stage, kept under laboratory conditions $\left(25^{\circ} \mathrm{C} \pm 5^{\circ} \mathrm{C}, 60 \% \pm 10 \% \mathrm{RH}, 14: 10 \mathrm{~L}: \mathrm{D}\right)$. The adults were transferred to PVC cages $(40 \mathrm{~cm}$ height $\times 30 \mathrm{~cm} \varnothing)$, internally coated with white standard paper sheets for oviposition, fed with a water-honey solution (9:1), kept under laboratory conditions $\left(25^{\circ} \mathrm{C} \pm 5^{\circ} \mathrm{C}, 60 \% \pm 10 \% \mathrm{RH}, 14: 10\right.$ 
L:D). The eggs were collected and stored in plastic bags kept in laboratory conditions until the hatch of caterpillars, thus keeping up the complete cycle and constant supply of individuals in the right age to be used in the experiments.

\subsection{Plants}

Twelve soybean cultivars were used in the experiment: Eight Bt soybean cultivars containing the Bt Cry1 Ac gene and four non-Bt (Table 1), additional information on the cultivars in Table S1. The cultivars were grown in $5 \mathrm{~L}$ plastic containers, placing 6 seeds per container, in V5 stage was performed the thinning, leaving only 3 plants per container.

\subsection{Attractiveness Index and Larval Preference in Free and No-Choice Tests}

The attractiveness indexes and larval preference were evaluated in free and no-choice tests conducted under laboratory conditions $\left(25^{\circ} \mathrm{C} \pm 2^{\circ} \mathrm{C}, 60 \% \pm 10 \%\right.$ $\mathrm{RH}, 14: 10 \mathrm{~L}: \mathrm{D})$, where leaf discs of different soybean cultivars were used.

In the free choice test, a third instar caterpillars, individualized, were released inside plastic circular arenas $(50 \mathrm{~cm} \emptyset \times 10 \mathrm{~cm}$ height), containing a leaf disc (5 $\mathrm{cm} \varnothing$ ) of each treatment. Before tests, the caterpillars were subjected to a 12 hour fasting. This assay was carried out using randomized blocks design with 24 replications.

In the no-choice test, the leaf disc of each cultivar were isolated in the center of a Petri dish $(8 \mathrm{~cm} \times 2 \mathrm{~cm})$, together with a third instar caterpillars. Each dish is a plot, with 24 repetitions per cultivar in a completely randomized design.

The evaluations for both the free and no-choice tests were performed every 1 , 2, 3, 6 and 12 hours after release. At the end of the counting the attractiveness

Table 1. Description of cultivars that were used in the experiments, adapting the name of the genotypes and main observed vegetative characteristics.

\begin{tabular}{cccccccc}
\hline Treatment & Cultivar & Technology & $\begin{array}{c}\text { Relative } \\
\text { maturation }\end{array}$ & Type of growth & Flower color & $\begin{array}{c}\text { Requirement } \\
\text { fertility }\end{array}$ & Lodging \\
\hline Bt1 & TMG 2183 & IPRO & 8.3 & Determined & Purple & High & Tolerant \\
Bt2 & M8210 & IPRO & 8.2 & Determined & White & High & Resistant \\
Bt3 & M 8644 & IPRO & 8.6 & Determined & Purple & High & Resistant \\
Bt4 & M 8372 & IPRO & 8.3 & Determined & White & High & Resistant \\
Bt5 & AS 3820 & IPRO & 8.2 & Determined & Purple & High & Moderate \\
Bt6 & M 8330 & IPRO & 8.3 & Determined & Purple & High & Resistant \\
Bt7 & HK 8314 & IPRO & 8.3 & Determined & White & High & Moderate \\
Bt8 & HK 8514 & IPRO & 8.5 & Determined & White & High & Moderate \\
RR1 & M 9144 & RR & 9.1 & Determined & Purple & Average & Moderate \\
RR2 & FTS Campo novo & RR & 8.3 & Undetermined & White & High & Resistant \\
RR3 & FTS Paragominas & RR & 9.3 & Determined & Purple & Average & Moderate \\
CONV & M 9350 & Conventional & 9.3 & Determined & Purple & Average & Moderate \\
\hline
\end{tabular}

Conv = Conventional: No event; RR = RR has events of tolerance to the herbicide glyphosate; Bt = IPRO (CrylAc and RR): two events, tolerance to glyphosate and protection against caterpillars. 
index was estimated, by the formula: $\mathrm{AI}=2 \mathrm{~T} /(\mathrm{T}+\mathrm{P})$ where: $\mathrm{AI}=$ Attractiveness Index, $\mathrm{T}=$ number of insects attracted to the evaluated cultivar, $\mathrm{P}=$ number of insects attracted to the standard cultivar. AI values range between zero and two, as follows: $\mathrm{AI}=1$ indicates similar attraction between the evaluated and standard cultivars, IA $<1$ corresponds to less attraction to cultivar, IA $>1$ indicates greater attraction to evaluated cultivar in relation to the standard one [19] [20] [21]. The cultivars were classified by comparing the ratios obtained in the evaluated cultivars and the standard cultivar.

Simultaneously to the attractiveness free and no-choice tests, evaluated the consumption of leaf discs by third instar caterpillars of $H$. armigera. The discs were measured, with the aid of leaf area meter LI $3000 \mathrm{~A}\left(\mathrm{Li}^{\left.-\mathrm{Cor}^{\circ}\right)}\right.$ to determine the area consumed by the caterpillars.

For both attractiveness free and no-choice tests and consumption of leaf discs, the data were submitted to analysis of variance by the $\mathrm{F}$ test and the means compared by the Tukey test, at 5\% probability, using the SAS statistical software [22].

\subsection{Attractiveness Index and Preference for Oviposition}

The attractiveness and oviposition preference were evaluated in free-choice tests in a greenhouse, coated with screened. For assembly, four vessels/cultivars were placed with three soybean plants each, in stages R3, the different cultivars in 30 $\mathrm{cm}$ spacings between vessels and $40 \mathrm{~cm}$ between rows of vessels. In the center of the greenhouse, $50 \mathrm{~cm}$ above the plants, it was released a $H$. armigera moth couple per soybean vessel, i.e., 48 couples were released at $6 \mathrm{am}$, and the evaluations of attractiveness were performed 6, 12, 24 and 48 hours after the release. At the end of the attractiveness test the attractiveness index was estimated. Oviposition was evaluated 72 hours after the release of insects, counting the number of eggs per soybean cultivars. The preference index was also calculated for oviposition by the equation: $\mathrm{POI}=[(\mathrm{TP}) /(\mathrm{T}+\mathrm{P})]^{*} 100$ where: $\mathrm{POI}=$ preference for oviposition index, $\mathrm{T}=$ number of eggs counted in cultivars, $\mathrm{P}=$ number of eggs counted in conventional cultivars, the index ranges from: +100 (very stimulating), -100 (total deterrence) and 0 indicates neutrality [21] [23] [24]. The cultivar used as a standard in the bioassays showed the most attractiveness and consumption in the free-choice test. The design was a randomized block with 12 treatments, with four replications. Each replication consists of a vase with three soybean plants.

After the evaluation the analysis of variance was carried out, and when there was a significant difference between cultivars, the Tukey test $(\mathrm{P}<0.05)$ was performed for the comparison of means, using the SAS statistical software [22].

\section{Results}

\subsection{Attractiveness and Attractiveness Index of Caterpillars in Free-Choice Test}

The time effect was significant, at all times of evaluations. For each time it was possible to find great variation among the cultivars with higher averages. How- 
ever, the best results were obtained by the cultivars Bt5 and Bt7, which maintained among the highest averages for all times evaluated, while the cultivars that presented lower means of attracted individuals were Bt8 and Conv (Table 2).

The attractiveness indexes varied between the evaluation times, with the most cultivars attracted at the $30 \mathrm{~min}, 1$ and 3 hours evaluation, while at 2, 6 and 12 hours were less attractive for most cultivars. The indexes varied among treatments, where Bt5 and RR3 treatments were more attractive in the first four evaluations while Bt8, RR1 and Conv were more repellent (Figure 1).

For the attractiveness no-choice bioassay, there was a variation among the evaluation times, with a more noticeable effect in the first evaluations. At the same time, there was a variation among treatments, where Bt2, Bt 3 and Bt8 had higher averages of attracted caterpillars and RR1 and RR3, in contrast, had lower averages of attracted caterpillars (Table 3 ).

The indices of attractiveness without choice differ between the evaluations times according to the formula used for evaluation. The best results for attractiveness were obtained in the first hours (Figures 2(a)-(c)) and more repellents in the latter (Figures 2(d)-(f)). Treatments Bt1, Bt5, RR1, RR3 and Conv showed higher repellency index when compared with treatments $\mathrm{Bt} 2, \mathrm{Bt} 3, \mathrm{Bt} 7$ and Bt8.

\subsection{Consumption with and without Choice}

The leaf area consumed in the free-choice test varied among treatments, being treatment RR2 the one that had the largest consumed area, while Bt1, Bt3 and

Table 2. Average number $( \pm$ SE) third instar Helicoverpa armigera caterpillar attracted in free-choice tests 30 min, 1, 2, 3, 6 and 12 hours after the release, for the different soybean cultivars.

\begin{tabular}{|c|c|c|c|c|c|c|}
\hline \multirow{2}{*}{ Cultivars } & \multicolumn{6}{|c|}{ Time (hours) } \\
\hline & $30 \mathrm{~min}$ & 1 & 2 & 3 & 6 & 12 \\
\hline Bt1 & $0.7 \pm 0.1 \mathrm{ABCab}$ & $1 \pm 0 \mathrm{Aa}$ & $0.7 \pm 0.1 \mathrm{ABab}$ & $0.4 \pm 0.1 \mathrm{BCbc}$ & $0.2 \pm 0.01 \mathrm{Cc}$ & $0.6 \pm 0.07 \mathrm{ABCb}$ \\
\hline Bt2 & $0.6 \pm 0.1 \mathrm{ABCbc}$ & $0.7 \pm 0.1 \mathrm{ABCab}$ & $0.4 \pm 0.07 \mathrm{ABCbc}$ & $0.3 \pm 0.04 \mathrm{Cc}$ & $0.3 \pm 0.03 \mathrm{BCc}$ & $1 \pm 0.1 \mathrm{Aa}$ \\
\hline Bt3 & $0.7 \pm 0.1 \mathrm{ABCab}$ & $0.5 \pm 0.01 \mathrm{BCDab}$ & $0.4 \pm 0.06 \mathrm{ABCb}$ & $0.8 \pm 0.09 \mathrm{Aba}$ & $0.5 \pm 0.07 \mathrm{ABCab}$ & $0.5 \pm 0.09 \mathrm{BCab}$ \\
\hline $\mathrm{Bt} 4$ & $0.5 \pm 0.04 \mathrm{BCb}$ & $0.5 \pm 0.04 \mathrm{BCDb}$ & $0.4 \pm 0.06 \mathrm{ABCb}$ & $0.4 \pm 0.04 \mathrm{BCb}$ & $0.2 \pm 0.03 \mathrm{Cb}$ & $0.5 \pm 0.02 \mathrm{BCb}$ \\
\hline Bt5 & $0.9+0.7 \mathrm{ABab}$ & $0.8+0.1 \mathrm{ABab}$ & $0.8+0.1 \mathrm{Aab}$ & $1+0.03 \mathrm{Aa}$ & $0.7+0.1 \mathrm{ABab}$ & $0.6+0.2 \mathrm{ABCb}$ \\
\hline Bt6 & $0.4 \pm 0.08 \mathrm{Cbc}$ & $0.5 \pm 0.09 \mathrm{BCDab}$ & $0.6 \pm 0.1 \mathrm{ABab}$ & $0.8 \pm 0.08 \mathrm{Aba}$ & $0.1 \pm 0.01 \mathrm{Cc}$ & $0.3 \pm 0.03 \mathrm{Cbc}$ \\
\hline Bt7 & $0.6 \pm 0.1 \mathrm{ABCab}$ & $0.6 \pm 0.1 \mathrm{ABCDab}$ & $0.7 \pm 0.1 \mathrm{ABab}$ & $0.9 \pm 0.07 \mathrm{Aa}$ & $0.5 \pm 0.09 \mathrm{ABCb}$ & $0.7 \pm 0.1 \mathrm{ABCab}$ \\
\hline Bt8 & $0.6 \pm 0.07 \mathrm{ABCa}$ & $0 ; 2 \pm 0.03 \mathrm{Db}$ & $0.4 \pm 0.03 \mathrm{ABCab}$ & $0.6 \pm 0.1 \mathrm{ABCa}$ & $0.4 \pm 0.06 \mathrm{ABCab}$ & $0.5 \pm 0.07 \mathrm{BCab}$ \\
\hline RR1 & $0.4 \pm 0.1 \mathrm{Cbc}$ & $0.3 \pm 0.03 \mathrm{CDc}$ & $0.4 \pm 0.1 \mathrm{ABCbc}$ & $0.7 \pm 0.1 \mathrm{ABCab}$ & $0.8 \pm 0.1 \mathrm{Aa}$ & $0.8 \pm 0.1 \mathrm{Aba}$ \\
\hline RR2 & $0.4 \pm 0.08 \mathrm{Cbc}$ & $0.5 \pm 0.1 \mathrm{BCDabc}$ & $0.5 \pm 0.1 \mathrm{ABCbc}$ & $0.3 \pm 0.04 \mathrm{Cc}$ & $0.7 \pm 0.1 \mathrm{ABab}$ & $0.8 \pm 0.1 \mathrm{Aba}$ \\
\hline RR3 & $1 \pm 0.07 \mathrm{Aa}$ & $0.8 \pm 0.08 \mathrm{ABab}$ & $0.5 \pm 0.07 \mathrm{ABCc}$ & $0.4 \pm 0.08 \mathrm{BCc}$ & $0.4 \pm 0.04 \mathrm{ABCc}$ & $0.3 \pm 0.03 \mathrm{Cc}$ \\
\hline Conv & $0.3 \pm 0.03 \mathrm{Cab}$ & $0.6 \pm 0.07 \mathrm{ABCDa}$ & $0.4 \pm 0.08$ BCab & $0.3 \pm 0.04 \mathrm{Cab}$ & $0.5 \pm 0.06 \mathrm{ABCab}$ & $0.5 \pm 0.08 \mathrm{BCab}$ \\
\hline
\end{tabular}

Averages followed by the same capital letter in the column and small letter in the row do not differ statistically among each other by Tukey test [P $>0.05, \mathrm{~F}=$ 4.8, CV = 50.7 (SAS Institute, 2002)]. 

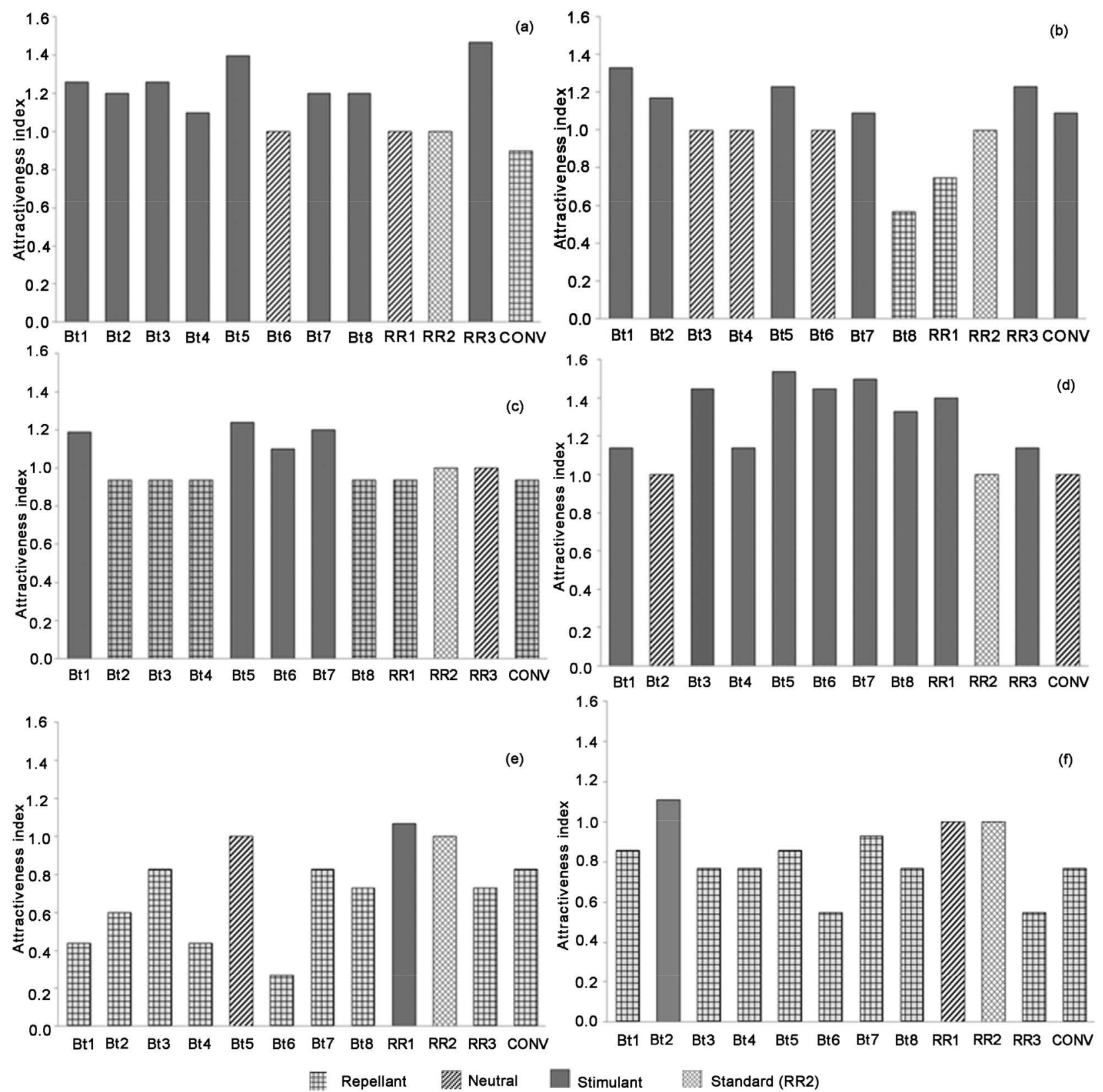

Figure 1. Attractiveness index of third instar Helicoverpa armigera caterpillars and soybean cultivars rating (a) 30 min; (b) 1 hour; (c) 2 hours; (d) 3 Hours; (e) 6 hours; and (f) 12 hours after the start of free-choice test.

Bt7 were the ones with smaller consumed areas (Figure 3(a)). For the no-choice test, there was a difference in the consumed area by the treatments, with RR1 standing out for the highest consumption and with smaller consumed areas, treatments Bt2, Bt4, Bt5, Bt6, Bt7, Bt8 and Conv (Figure 3(b)).

\subsection{Attractiveness and Attractiveness Index of Adult Helicoverpa armigera}

The time effect was significant showing that the moths have different behavior in exposure times. There was difference for moths' landing preference among cultivars 
Table 3. Average number ( \pm SE) third instar Helicoverpa armigera caterpillar attracted in no-choice tests 30 min, $1,2,3,6$ and 12 hours after the release, for the different soybean cultivars.

\begin{tabular}{|c|c|c|c|c|c|c|}
\hline \multirow{2}{*}{ Cultivars } & \multicolumn{6}{|c|}{ Time (hours) } \\
\hline & $30 \mathrm{~min}$ & 1 & 2 & 3 & 6 & 12 \\
\hline Bt1 & $0.7 \pm 0.1 \mathrm{BCa}$ & $0.3 \pm 0.07 \mathrm{DEb}$ & $0.5 \pm 0.09 \mathrm{Aab}$ & $0.6 \pm 0.08 \mathrm{ABab}$ & $0.4 \pm 0.05 \mathrm{ABab}$ & $0.5 \pm 0.09 \mathrm{ABab}$ \\
\hline Bt2 & $1.1 \pm 0.6 \mathrm{Aa}$ & $0.8 \pm 0.08 \mathrm{ABab}$ & $0.5 \pm 0.09 \mathrm{Abcd}$ & $0.3 \pm 0.06 \mathrm{Bd}$ & $0.4 \pm 0.08 \mathrm{ABcd}$ & $0.6 \pm 0.1 \mathrm{ABbcd}$ \\
\hline Bt3 & $1 \pm 0.02 \mathrm{ABab}$ & $1.1 \pm 0.07 \mathrm{Aa}$ & $0.6 \pm 0.07 \mathrm{Ac}$ & $0.6 \pm 0.09 \mathrm{ABc}$ & $0.6 \pm 0.05 \mathrm{Ac}$ & $0.4 \pm 0.07 \mathrm{ABCc}$ \\
\hline Bt4 & $0.6 \pm 0.07 \mathrm{Cab}$ & $0.8 \pm 0.08 \mathrm{ABa}$ & $0.7 \pm 0.09 \mathrm{Aa}$ & $0.3 \pm 0.06 \mathrm{Bb}$ & $0.6 \pm 0.1 \mathrm{Aab}$ & $0.6 \pm 0.1 \mathrm{ABab}$ \\
\hline Bt5 & $0.6 \pm 0.1 \mathrm{Ca}$ & $0.7 \pm 0.1 \mathrm{BCa}$ & $0.5 \pm 0.1 \mathrm{Aa}$ & $0.5 \pm 0.1 \mathrm{ABa}$ & $0.5 \pm 0.09 \mathrm{Aba}$ & $0.1 \pm 0.02 \mathrm{Cb}$ \\
\hline Bt6 & $0.7 \pm 0.08 \mathrm{BCab}$ & $0.6 \pm 0.1 \mathrm{BCDbc}$ & $0.5 \pm 0.09 \mathrm{Abc}$ & $0.4 \pm 0.07 \mathrm{Bbc}$ & $0.6 \pm 0.07 \mathrm{Abc}$ & $0.3 \pm 0.07 \mathrm{BCc}$ \\
\hline Bt7 & $0.7 \pm 0.1 \mathrm{BCa}$ & $0.7 \pm 0.1 \mathrm{BCa}$ & $0.6 \pm 0.1 \mathrm{Aab}$ & $0.8 \pm 0.08 \mathrm{Aa}$ & $0.5 \pm 0.09 \mathrm{ABab}$ & $0.3 \pm 0.04 \mathrm{BCb}$ \\
\hline Bt8 & $0.8 \pm 0.08 \mathrm{ABCb}$ & $0.7 \pm 0.1 \mathrm{BCb}$ & $0.6 \pm 0.2 \mathrm{Abc}$ & $0.3 \pm 0.08 \mathrm{Bc}$ & $0.7 \pm 0.08 \mathrm{Ab}$ & $0.5 \pm 0.07 \mathrm{ABbc}$ \\
\hline RR1 & $0.2 \pm 0.05 \mathrm{DEb}$ & $0.1 \pm 0.02 \mathrm{~Eb}$ & $0.4 \pm 0.08 \mathrm{Aab}$ & $0.6 \pm 0.1 \mathrm{ABa}$ & $0.7 \pm 0.08 \mathrm{Aa}$ & $0.7 \pm 0.1 \mathrm{Aa}$ \\
\hline RR2 & $0.6 \pm 0.07 \mathrm{Ca}$ & $0.4 \pm 0.04 \mathrm{CDEa}$ & $0.5 \pm 0.09 \mathrm{Aa}$ & $0.5 \pm 0.09 \mathrm{ABa}$ & $0.6 \pm 0.1 \mathrm{Aa}$ & $0.7 \pm 0.08 \mathrm{Aa}$ \\
\hline RR3 & $0.1 \pm 0.2 \mathrm{~Eb}$ & $0.3 \pm 0.02 \mathrm{DEab}$ & $0.5 \pm 0.07 \mathrm{Aa}$ & $0.3 \pm 0.05 \mathrm{Bab}$ & $0.2 \pm 0.03 \mathrm{Bab}$ & $0.3 \pm 0.04 \mathrm{BCab}$ \\
\hline Conv & $0.5 \pm 0.1 \mathrm{CDab}$ & $0.4 \pm 0.1 \mathrm{CDEab}$ & $0.7 \pm 0.1 \mathrm{Aa}$ & $0.5 \pm 0.1 \mathrm{ABab}$ & $0.4 \pm 0.1 \mathrm{ABab}$ & $0.3 \pm 0.03 \mathrm{BCb}$ \\
\hline
\end{tabular}

Averages followed by the same capital letter in the column do not differ statistically among each other by Tukey test $[\mathrm{P}>0.05, \mathrm{~F}=6, \mathrm{CV}=49.71$ (SAS Institute, 2002)].

depending on the evaluation time (Table 4). Evaluations between 12 and 24 hours of exposure showed greater preference for $H$. armigera moths' landing. Treatments Bt7, Bt8 and Conv had lower averages of attracted individuals, while Bt6 was had the highest landing preference.

Through the attractiveness index of adult $H$. armigera obtained 6 hours after the release (Figure 4(a)) it was found attractiveness to most treatments, where only treatments Bt4, Bt7 and Bt8 were classified as repellents. After 12 hours the attractiveness index dropped, and only treatment Bt7 remained attractive when compared to the standard genotype (RR2) (Figure 4(b)).

After 24 hours after the release, treatments Bt5, Bt6, RR1, RR3 and Conv were rated as attractive, especially Bt 6 and RR1 with a higher attractiveness index, being the other treatments classified as repellents (Figure 4(c)). For evaluation of the attractiveness in 48 hours, treatments Bt7, Bt8 and Conv were classified as repellents, while the others were attractive, especially treatment $\mathrm{Bt} 3$, due to its higher attractiveness index (Figure $4(\mathrm{~d})$ ).

\subsection{Preference and Preference Index for Oviposition}

There were significant differences among cultivars in all thirds of the evaluated plant for $H$. armigera oviposition (Table 5). For most of the studied cultivars, oviposition behavior was more concentrated on the upper third of the plant, except for Bt 1 and $\mathrm{Bt} 5$ which obtained the highest average number of eggs on the middle third of the plant.

For treatments Bt1, Bt6 and RR3, the oviposition did not distinguish the parts of the plant, with no difference in the average among the lower, middle and 


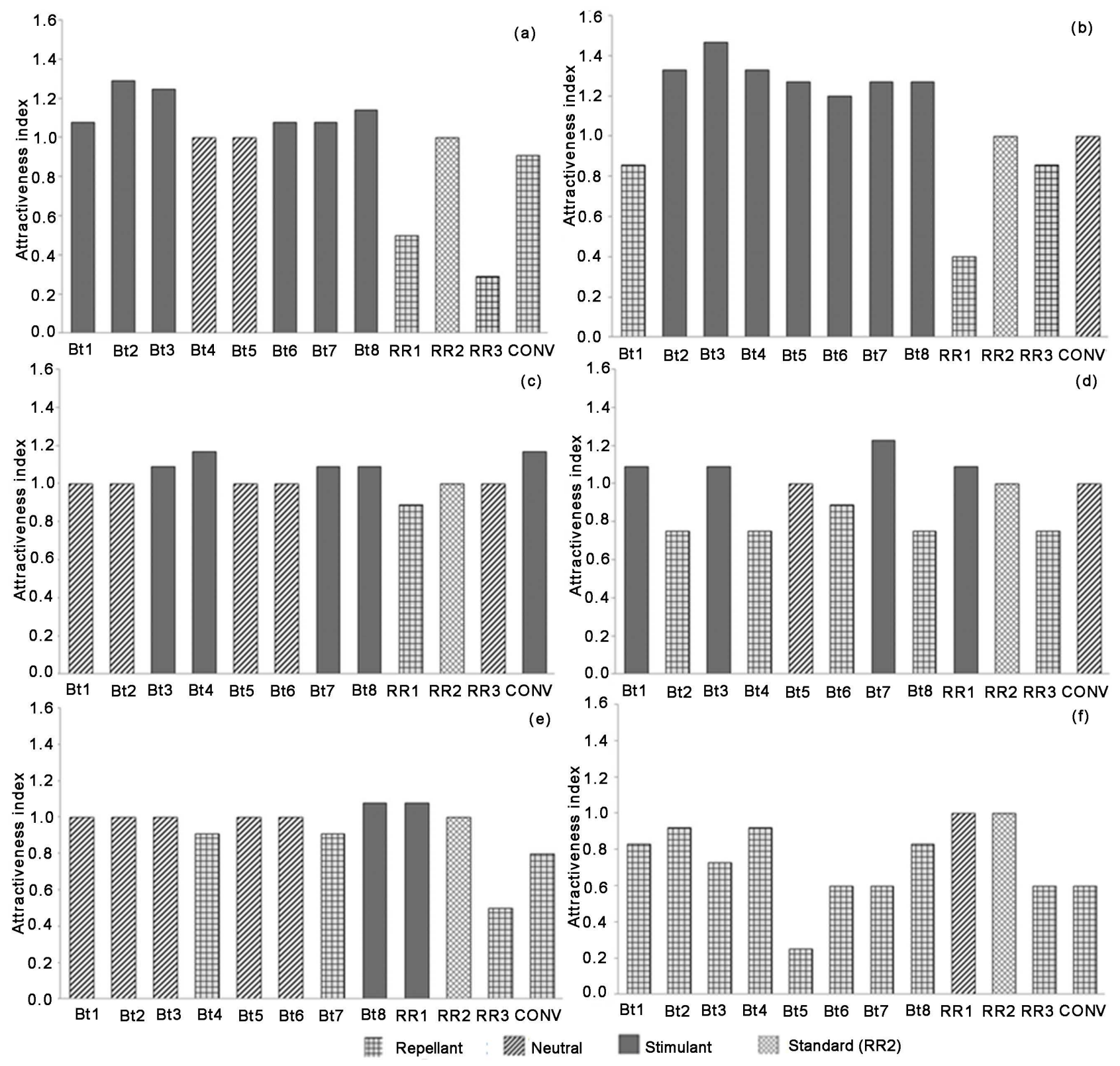

Figure 2. Attractiveness index of third instar Helicoverpa armigera caterpillars and soybean cultivars rating (a) $30 \mathrm{~min}$; (b) 1 hour; (c) 2 hours; (d) 3 hours; (e) 6 hours; and (f) 12 hours after the start of no-choice test.

upper third of the plant. In contrast, Bt4, RR1 and RR2 were the treatments with the lowest egg average (Table 5).

The preference index for free-choice oviposition on the lower third of the plant (Figure 5(a)) reveals a contrast among the standard treatment (RR2) and treatments Bt3, Bt4, Bt5, RR1 and Conv, which were classified as deterrents. On the other hand, Bt1, Bt2, Bt6, Bt7, Bt8 and RR3 were considered stimulants to the oviposition of $H$. armigera, especially for Bt1, Bt2 and Bt6 which had higher preference indexes.

On the middle third, only treatment RR1 was classified as a deterrent, with the others considered stimulants when compared to the standard one (Figure 5(b)). 


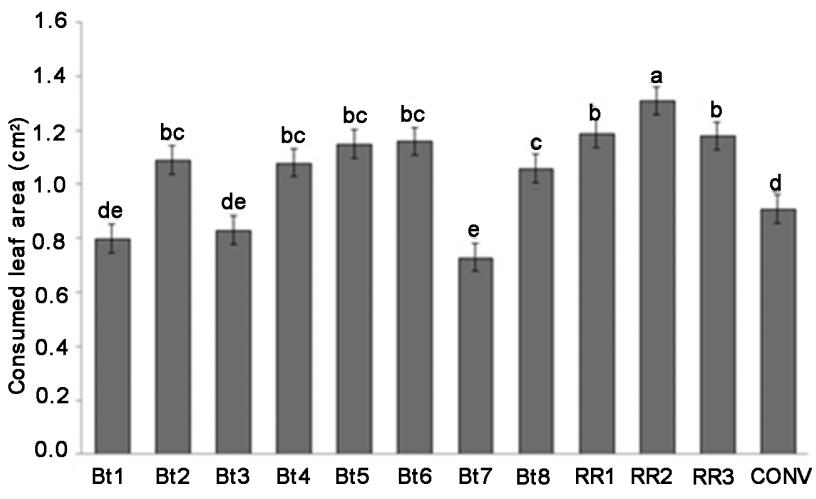

(a)

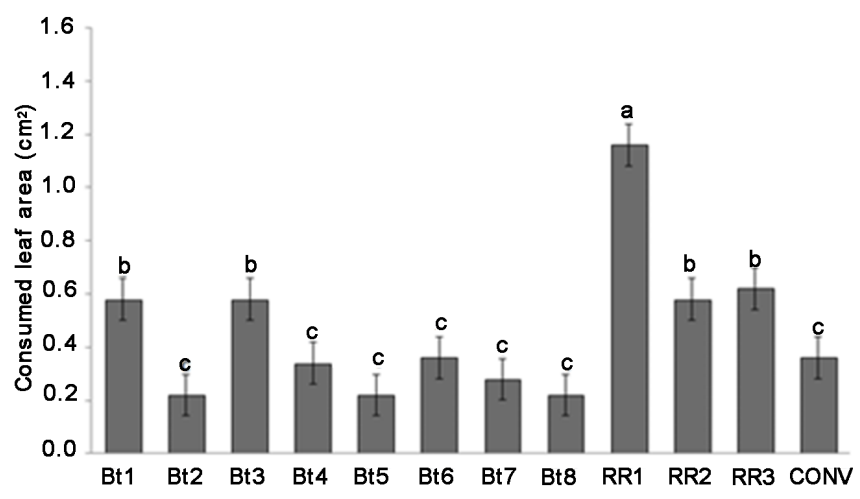

(b)

Figure 3. Consumed leaf area $\left(\mathrm{cm}^{2}\right)$ by third instar Helicoverpa armigera caterpillars (a) Obtained in free-choice test; and (b) Obtained in no-choice test, in different soybean cultivars. Averages followed by the same letter do not differ statistically by Tukey test at $5 \%$ significance level.

Table 4. Average number $( \pm \mathrm{SE})$ adult Helicoverpa armigera attracted in free-choice tests 30 min, 1, 6, 12, 24 and 48 hours after the release, for the different soybean cultivars in greenhouse.

\begin{tabular}{|c|c|c|c|c|c|}
\hline \multirow{2}{*}{ CULTIVAR } & \multicolumn{4}{|c|}{ Time (hours) } & \multirow{2}{*}{ AVERAGE } \\
\hline & 6 & 12 & 24 & 48 & \\
\hline Bt1 & $1 \pm 0 \mathrm{CDb}$ & $1.5 \pm 0.04 \mathrm{BCa}$ & $0.5 \pm 0.1 \mathrm{EFc}$ & $0.5 \pm 0.04 \mathrm{Bc}$ & $0.88 \pm 0.11 \mathrm{CD}$ \\
\hline Bt2 & $1 \pm 0 \mathrm{CDa}$ & $0.75 \pm 0.14 \mathrm{Da}$ & $0.25 \pm 0.05 \mathrm{FGb}$ & $0.25 \pm 0.03 \mathrm{BCb}$ & $0.56 \pm 0.09 \mathrm{E}$ \\
\hline Bt3 & $1.75 \pm 0.14 \mathrm{Aa}$ & $1.25 \pm 0.1 \mathrm{BCDb}$ & $0 \pm 0 \mathrm{Gc}$ & $1.25 \pm 0.1 \mathrm{Ab}$ & $1.06 \pm 0.17 \mathrm{BC}$ \\
\hline Bt4 & $0.25 \pm 0.02 \mathrm{~Eb}$ & $1 \pm 0 \mathrm{CDa}$ & $0.5 \pm 0.1 \mathrm{EFb}$ & $0.5 \pm 0.06 \mathrm{Bb}$ & $0.56 \pm 0.08 \mathrm{E}$ \\
\hline Bt5 & $0.75 \pm 0.1 \mathrm{Db}$ & $1.25 \pm 0.10 \mathrm{BCDa}$ & $1 \pm 0 \mathrm{CDab}$ & $0.25 \pm 0.05 \mathrm{BCc}$ & $0.81 \pm 0.1 \mathrm{D}$ \\
\hline Bt6 & $1.25 \pm 0.03 \mathrm{BCc}$ & $2.5 \pm 0.29 \mathrm{Aa}$ & $1.75 \pm 0.14 \mathrm{Ab}$ & $0.25 \pm 0.03 \mathrm{BCd}$ & $1.44 \pm 0.22 \mathrm{~A}$ \\
\hline Bt7 & $0.25 \pm 0.03 \mathrm{~Eb}$ & $0.75 \pm 0.14 \mathrm{Da}$ & $0 \pm 0 \mathrm{~Gb}$ & $0 \pm 0 \mathrm{Cb}$ & $0.25 \pm 0.09 \mathrm{~F}$ \\
\hline Bt8 & $0.25 \pm 0.02 \mathrm{Eab}$ & $0.25 \pm 0.05 \mathrm{Eab}$ & $0.5 \pm 0.1 \mathrm{EFa}$ & $0 \pm 0 \mathrm{Cb}$ & $0.25 \pm 0.05 \mathrm{~F}$ \\
\hline RR1 & $1.25 \pm 0.03 \mathrm{BCb}$ & $1.75 \pm 0.25 \mathrm{Ba}$ & $1.5 \pm 0.10 \mathrm{ABab}$ & $0.25 \pm 0.05 \mathrm{BCc}$ & $1.19 \pm 0.16 \mathrm{~B}$ \\
\hline RR2 & $0.75 \pm 0.10 \mathrm{Db}$ & $1.75 \pm 0.14 \mathrm{Ba}$ & $0.75 \pm 0.14 \mathrm{DEb}$ & $0 \pm 0 \mathrm{Cc}$ & $0.81 \pm 0.17 \mathrm{D}$ \\
\hline RR3 & $1.25 \pm 0.03 \mathrm{BCa}$ & $1.25 \pm 0.14 \mathrm{BCDa}$ & $1 \pm 0.1 \mathrm{CDa}$ & $0.25 \pm 0.05 \mathrm{BCb}$ & $0.94 \pm 0.11 \mathrm{CD}$ \\
\hline Conv & $1.5 \pm 0.04 \mathrm{Aba}$ & $1 \pm 0.2 \mathrm{CDb}$ & $1.25 \pm 0.14 \mathrm{BCab}$ & $0 \pm 0 \mathrm{Cc}$ & $0.94 \pm 0.16 \mathrm{CD}$ \\
\hline
\end{tabular}

Averages followed by the same capital letter in the column and small letter in the row do not differ statistically among each other by Tukey test $[\mathrm{P}>0.05, \mathrm{~F}=13, \mathrm{CV}=25$ (SAS Institute, 2002)].

On the upper third, all treatments were classified as stimulants in relation to the standard cultivar, with Bt6 and RR3 standing out due to their higher preference for oviposition index (Figure 5(c)).

In the preference index, considering the overall average in the whole plant, all treatments were classified as stimulants for oviposition, with Bt1, Bt6 and RR3 (Figure 5(d)) standing out for their higher preference indexes, while RR1 was the less stimulating treatment on the upper third of the plant and deterrent on the lower and middle thirds. 


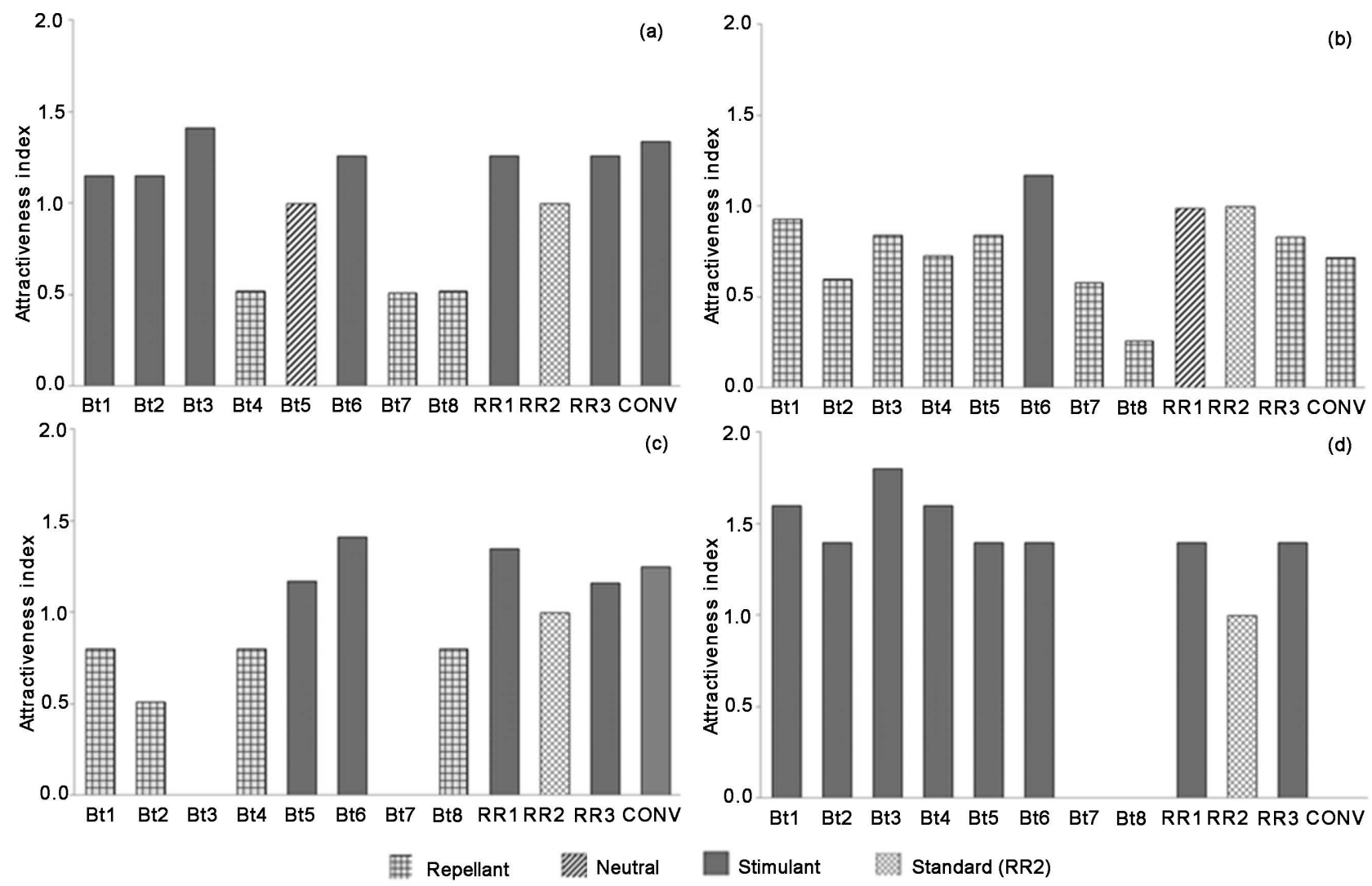

Figure 4. Adult Helicoverpa armigera attractiveness index and soybean cultivars rating, (a) 6 hour; (b) 12 hours; (c) 24 hours; and (d) 48 hours in free-choice tests in greenhouse.

Table 5. Average number $( \pm \mathrm{SE})$ Helicoverpa armigera eggs obtained in free-choice tests after 72 hours from the release, for the different soybean cultivars in greenhouse.

\begin{tabular}{ccccc}
\hline \multirow{2}{*}{ CULTIVAR } & \multicolumn{4}{c}{ Plant third } \\
\cline { 2 - 5 } & Lower & Middle & Higher & Total \\
\hline Bt1 & $8.75 \pm 0.25 \mathrm{Ab}$ & $22 \pm 0.82 \mathrm{Aa}$ & $11.50 \pm 1.19 \mathrm{BCb}$ & $42.25 \pm 1.38 \mathrm{~A}$ \\
$\mathrm{Bt} 2$ & $5.5 \pm 0.28 \mathrm{Bb}$ & $6.25 \pm 0.48 \mathrm{Bb}$ & $12 \pm 0.41 \mathrm{BCa}$ & $23.75 \pm 0.63 \mathrm{BC}$ \\
$\mathrm{Bt} 3$ & $0.5 \pm 0.04 \mathrm{Fc}$ & $4.75 \pm 0.48 \mathrm{Bb}$ & $12.75 \pm 1.03 \mathrm{Ba}$ & $18 \pm 1.47 \mathrm{C}$ \\
$\mathrm{Bt} 4$ & $0.25 \pm 0.05 \mathrm{Fc}$ & $5.5 \pm 0.29 \mathrm{Bb}$ & $12.75 \pm 0.85 \mathrm{Ba}$ & $18.5 \pm 0.62 \mathrm{D}$ \\
$\mathrm{Bt} 5$ & $0.25 \pm 0.02 \mathrm{Fc}$ & $16.25 \pm 0.48 \mathrm{Aa}$ & $12.75 \pm 0.48 \mathrm{Bb}$ & $29.25 \pm 0.81 \mathrm{~B}$ \\
$\mathrm{Bt6}$ & $3.25 \pm 0.14 \mathrm{CDb}$ & $4.25 \pm 0.25 \mathrm{Bb}$ & $34.25 \pm 1.65 \mathrm{Aa}$ & $41.75 \pm 1.96 \mathrm{~A}$ \\
$\mathrm{Bt} 7$ & $1.75 \pm 0.14 \mathrm{DEFc}$ & $8.25 \pm 0.63 \mathrm{Bb}$ & $12 \pm 0.71 \mathrm{BCa}$ & $22 \pm 0.54 \mathrm{BC}$ \\
$\mathrm{Bt} 8$ & $4 \pm 0.2 \mathrm{BCb}$ & $6.25 \pm 0.25 \mathrm{Bb}$ & $9.75 \pm 0.48 \mathrm{BCDa}$ & $20 \pm 0.68 \mathrm{C}$ \\
$\mathrm{RR} 1$ & $0 \pm 0 \mathrm{Fb}$ & $2.25 \pm 0.25 \mathrm{Bb}$ & $7.75 \pm 0.25 \mathrm{CDa}$ & $9.25 \pm 0.41 \mathrm{D}$ \\
$\mathrm{RR} 2$ & $1 \pm 0 \mathrm{EFb}$ & $2.75 \pm 0.25 \mathrm{Bab}$ & $5.75 \pm 0.48 \mathrm{Da}$ & $9.5 \pm 0.29 \mathrm{D}$ \\
$\mathrm{RR} 3$ & $275 \pm 0.25 \mathrm{CDEb}$ & $5 \pm 0.41 \mathrm{Bb}$ & $34 \pm 0.82 \mathrm{Aa}$ & $41.75 \pm 0.63 \mathrm{~A}$ \\
CONV & $0.75 \pm 0.14 \mathrm{EFc}$ & $6.75 \pm 0.48 \mathrm{Bb}$ & $11.75 \pm 0.95 \mathrm{BCa}$ & $19.25 \pm 0.92 \mathrm{C}$ \\
\hline
\end{tabular}

Averages followed by the same capital letter in the column and small letter in the row do not differ statistically among each other by Tukey test at $5 \%$ significance level $[\mathrm{P}>0.05, \mathrm{~F}=129, \mathrm{CV}=13.67$ (SAS Institute, 2002)]. 

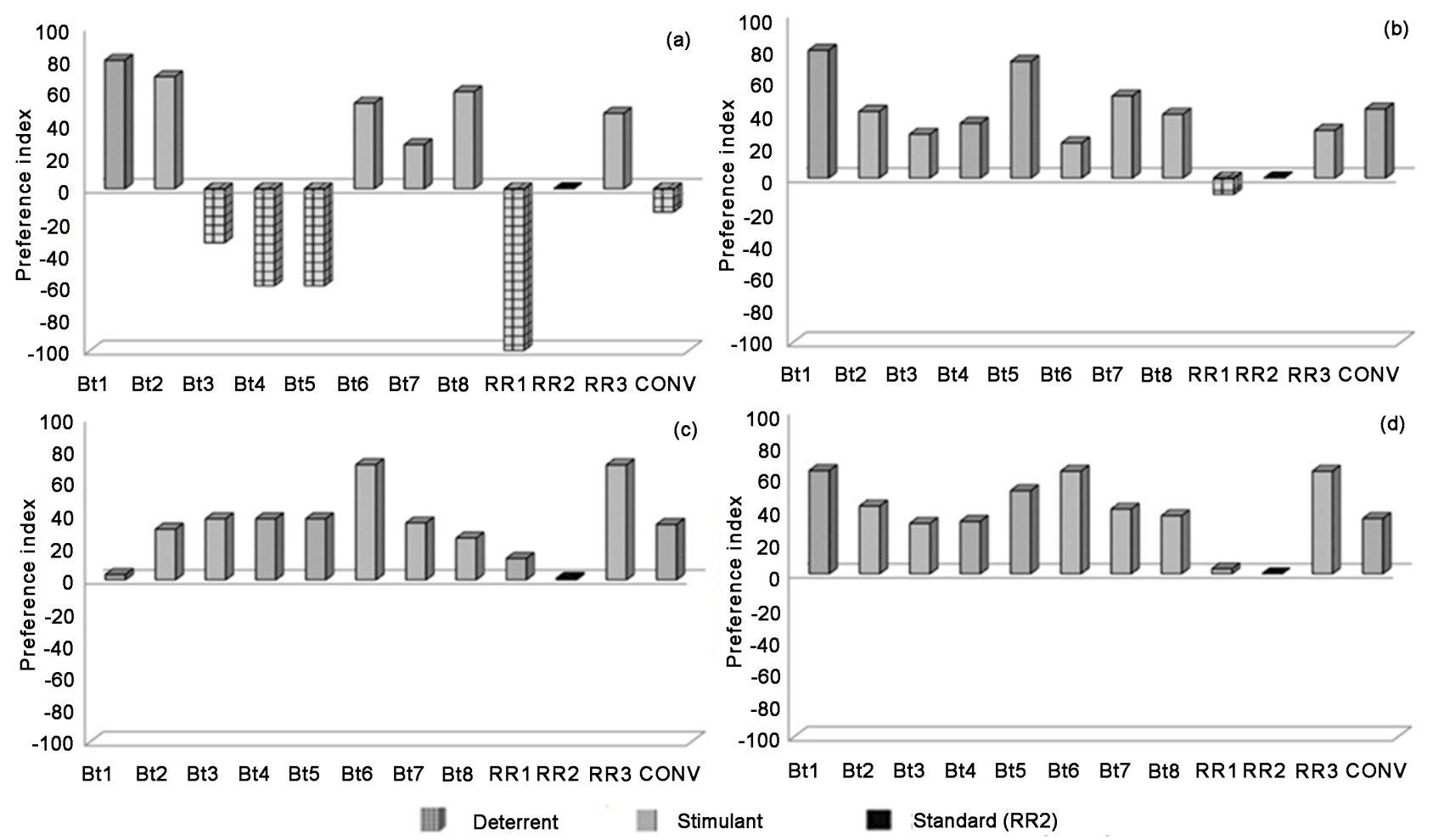

Figure 5. Preference index for Helicoverpa armigera and soybean cultivars classification on the (a) Lower third; (b) Middle third; (c) Upper thirds; and (d) All parts of the plant after 72 hours in free-choice test in the greenhouse.

\section{Discussion}

Third instar $H$. armigera caterpillars showed attractiveness in free and no-choice test for food between Bt and non-Bt soybean leaves when simultaneously contrasting the tested cultivars. With respect to an insect's feeding preference for a particular plant genotype, the responses vary in relation to the stimuli coming from the plant, which may be positive or negative, and of chemical (allelochemicals), physical (color) or morphological (hairiness, hardness, texture, thickness, structures dimensions) nature. It is important to highlight that both stimuli (positive and negative) are present in the plant, in a way that the insect response depends on what stimulus overpowers the other [25].

The attractiveness and feeding preference found for some cultivars for $H$. armigera caterpillars demonstrate that CrylAc toxin had no effect on the preference and feeding and that these results are related to the physical and nutritional factors of cultivars. Kumar and Saini [26] reported that total phenols, gossypol, tannin and potassium are negatively correlated, while total sugars, proteins and nitrogen are positively correlated with the infestation of $H$. armigera caterpillars on different cotton cultivars. Loung et al. [27] reported similar results for $H$. armigera first instar caterpillars on Bt and non-Bt cotton. However, in this same work, they found that after six days there was a low percentage of survival of caterpillars susceptible to Bt plants. As a practical implication, in spite of proving the efficiency of Bt plants, their use without due care regarding the rotation of $\mathrm{Bt}$ 
cultivars, as well as the use of shelters can favor the resistance in the field due to the high selection pressure due to non-destination between Bt and non-Bt plants [28].

There was no difference between the attractiveness index for Bt and non-Bt treatments, demonstrating the plant resistance to $H$. armigera, and emphasizing the nutritional status of plants as a factor capable of influencing the attractiveness [29].

Yamasaki and Fujisaki [30] in studies on the $H$. armigera feeding preference and performance in Cosmos bipinnatus Cav. (Asteraceae) suggest that nutritional quality as well as substances such as secondary metabolites may have negative effects on larval development, which can influence the larval preference. It is also important to note that the presence of the compounds induced by herbivory becomes a constant in the chemical composition of the plant, insects can, over the generations, adapt to adverse conditions, developing defense mechanisms [25].

For Baghery et al. [31], nutritional indices are important factors that can determine plant resistance to insects. The analysis of feeding parameters, as well as their conversion, can help to understand the behavior of populations in the field [32], favoring the use of effective management.

According to the feeding behavior of $H$. armigera, there is no preference in leaf consumption between Bt plants and Bt not comparing bioassays with and without choice. It shows that $H$. armigera has no choice behavior between soybeans with and without Bt toxin, probably due to the rapid evolution of the resistance of $H$. armigera to Bacillus thuringiensis (Bt), this rapid evolution of resistance to Bt crops in several pests has reduced these benefits [33]. Rao and Rao [34] reported that third stage $H$. armigera larvae were repelled after the first bite of Bt plant.

For attractiveness and attractiveness for oviposition index of Helicoverpa armigera, there was variation in the choice for landing in time, however, there was no difference between Bt and non-Bt soybean treatments. Torres and Ruberson [35] found no difference in the landing preference of Heliothis virescens (Fabricius) and Helicoverpazea (Boddie) (Lepidoptera: Noctuidae) between $\mathrm{Bt}$ and non-Bt cotton. Thus, maintaining the attractiveness to Bt plants favors the greatest number of caterpillars in the area, which demonstrates the potential use of genetically modified plants to keep balanced the insect-pest population.

Treatments Bt7 and Bt 8 were considered repellants for $H$. armigera, suggesting that the physical and chemical factors act in different ways among cultivars and these factors are fundamentally important for the behavioral analysis of insects [36].

Chemical factors such as the volatile compounds are related to the location mechanisms of some species of moths. Tingle et al. [37] in studies using $H$. virescens moths, reported that they responded positively to the extracts of appropriate host plants and did not fly against the wind in response to the odor of a resistant tobacco cultivar and extracts of non-host plants, suggesting that specific 
volatile compounds play a role in the positioning for landing and oviposition. Furthermore, after landing on a host plant, $H$. virescens was able to discriminate between host plants by chemicals on the leaf surface using chemoreceptors in the tarsal [30] [38].

The major volatile compounds capable of triggering antennal response in $H$ armigera, are alpha-pinene and beta-pinene, which are 5.5 and 2.85 times higher in Bt cotton than in non-Bt cotton, respectively. These compounds may induce greater preference in Bt plants than in non-Bt cotton in the field. In addition, tannins, which play an important role in resistance to arthropod pests in cotton, are also lower in Bt plants [39] [40].

For the study of oviposition, $H$. armigera moths were not able to differentiate the treatments containing the Bt protein, where treatment RR1 (non-Bt) showed less preference for oviposition. The preference of $H$. armigera for a specific host can be influenced by the physiological state of the plant, including age, type of feeding of the larvae and adults mating that can perceive differences in the quality of the plant by the nutrient requirements of the pest or differences in the levels of secondary compounds. The presence of certain phytochemicals in soybean cultivars as antixenotic agents or the absence of primary nutrients essential for growth and development of $H$. armigera can compromise their development, keeping the population below the economic damage level [41].

The high number of eggs in Bt cultivars may be related to the fact that plants containing the Bt protein promote the attractiveness produced by volatile compounds. The insertion of genes in Bt cotton plants is known for inducing significant changes in relevant secondary compounds related to plant-herbivores interactions [42]. Thus, it is important to study and know whether there is a change in the composition of secondary compounds capable of triggering a positive response in the plant-herbivore interaction.

The highest number of eggs in both Bt and non-Bt soy treatments occurred on the middle and upper thirds of the plant, justifying the habit of this species that prefers buds, flowers and pods. $H$. armigera eggs are generally concentrated on the upper third of cotton plants and most eggs are usually laid near plants terminals [43].

As time passes the physiological behavior of pests may change in relation to $\mathrm{Bt}$ cultivars, but it's also possible to occur a genetic evolution where the pest species can avoid the main host and prefer the non-Bt host which until then were alternative hosts, such as other crops or weeds [27] [44]. As resistance mechanism, female moths can also change their behavior and select parts of plants without or with low expression of toxins for oviposition. This change in behavior may allow them to avoid caterpillars to hatch in direct contact with high concentrations of toxins and provides greater survival and dispersal of species [45].

This study showed that Bt toxin did not influence the oviposition preference, $H$. armigera adults did not differentiate $\mathrm{Bt}$ and non-Bt soybean cultivars for oviposition indicating no behavioral preference. Third instar caterpillars showed no discrimination between Bt and non-Bt soybean leaves. Research in this area 
must focus on the possibility of widespread planting of genetically modified soybeans containing the Bt protein, which is associated with selection pressure and the behavior of pest species in relation to their hosts, as well as on the adequacy of management tactics that are able to prevent the loss of technology efficiency.

\section{References}

[1] Cunningham, J.P. and Zalucki, M.P. (2014) Understanding Heliothine (Lepidoptera: Heliothinae) Pests: What Is a Host Plant? Journal of Economic Entomologic, 107, 881-896. https://doi.org/10.1603/EC14036

[2] Saber, M., Parsaeyan, E., Vojoudi, S., Bagheri, M., Mehrvar, A. and Kamita, S.G. (2013) Acute Toxicity and Sublethal Effects of Methoxyfenozide and Thiodicarb on Survival, Development and Reproduction of Helicoverpa armigera (Lepidoptera: Noctuidae). Crop Protection, 43, 14-17. https://doi.org/10.1016/j.cropro.2012.09.011

[3] Singh, A.K., Singh, A. and Joshi, P. (2016). Combined Application of Chitinolytic Bacterium Paenibacillussp. D1 with Low Doses of Chemical Pesticides for Better Control of Helicoverpa armigera. International Journal of Pest Management, 62, 222-227. https://doi.org/10.1080/09670874.2016.1167267

[4] Aheer, G.M., Aziz, M.A., Hameed, A. and Ali, A. (2009) Evaluation of Resistance to Different Insecticides in Field Strains of Helicoverpa armigera (Lepidoptera: Noctuidae) in Punjab, Pakistan. Entomological Research, 39, 159-167. https://doi.org/10.1111/j.1748-5967.2009.00210.x

[5] McDonald, B.A. (2015) How Can Research on Pathogen Population Biology Suggest Disease Management Strategies? The Example of Barley Scald (Rhynchosporium Commune). Plant Pathology, 64, 1005-1013. https://doi.org/10.1111/ppa.12415

[6] Zhang, H., Yin, W., Zhao, J., Jin, L., Yang, Y., Wu, S., Tabashnik, B.E. and Wu, Y. (2011) Early Warning of Cotton Bollworm Resistance Associated with Intensive Planting of Bt Cotton in China. PLoS One, 6, e22874. https://doi.org/10.1371/journal.pone.0022874

[7] Kogan, M. and Ortman, E.F. (978) Antixenosis: A New Term Proposed to Define Painter's Nonpreference Modality of Resistance. The Bulletin of the Ecological Society of America, 24, 175-176.

[8] Lambert, L. and Kilen, T. (1984) Multiple Insect Resistance in Several Soybean Genotypes. Crop Science, 24, 887-890.

https://doi.org/10.2135/cropsci1984.0011183X002400050014x

[9] Moreira, G.R., Silva, D.J.H., Carneiro, P.C.S., Picanço, M.C., Vasconcelos, A.A. and Pinto, C.M.F. (2013) Inheritance of Resistance Traits by Solanum pennellii antixose to Tomato Moth at Crossroads with "Santa Clara". Horticultura Brasileira, 31, 574-581. https://doi.org/10.1590/S0102-05362013000400011

[10] Dhillon, M.K., Sharma, H.C., Singh, R. and Naresh, J.S. (2005) Mechanisms of Resistance to Shoot Fly, Atherigona soccata in Sorghum. Euphytica, 144, 301-312. https://doi.org/10.1007/s10681-005-7400-4

[11] Fancelli, M., Vendramim, J.D. and Lourenção, A.L. (2008) Oviposition and Dispersal of Bemisia tabaci Nymphs B Biotype in Tomato Genotypes. Bragantia, 67, 933-939. https://doi.org/10.1590/S0006-87052008000400016

[12] Frelichowski Jr, J.E. and Juvik, J.A. (2005). Inheritance of Sesquiterpene Carboxylic Acid Synthesis in Crosses of Lycopersicon hirsutum with Insect-Susceptihie Toma- 
toes. Platit Breeding, 124, 277-281.

https://doi.org/10.1111/j.1439-0523.2005.01076.x

[13] Khush, G.S. and Panda, N. (1996) Host Plant Resistance to Insects. Bulletin of Entomological Research, 86, 315-316.

[14] Lara, F.M. (1991) Principles of Plant Resistance to Insects. 2nd Edition, ícone, São Paulo.

[15] Frankenhuyzen, K.V. (2009) Insecticidal activity of Bacillus thuringiensis Crystal Proteins. Journal of Invertebrate Pathology, 101, 1-16. https://doi.org/10.1016/j.jip.2009.02.009

[16] Schünemann, R., Knaak, N. and Fiuza, L.M. (2014) Mode of Action and Specificity of Bacillus thuringiensis Toxins in the Control of Caterpillars and Stink Bugs in Soybean Culture. Microbiology, 2014, 1-12.

[17] Ibrahim, M.A., Griko, N., Junker, M. and Bulla, L.A. (2010) Bacillus thuringiensis A Genomics and Proteomics Perspective Bioengineered Bugs. Landes Bioscience, 1, 31-50.

[18] Kasten Júnior, P., Precetti, A.A.C.M. and Parra, J.R.P. (1978) Comparative Biological Data of Spodoptera frugiperda (J. E. Smith, 1797) in Two Artificial Diets and Natural Substrate. Revista Engenharia Agricola, 53, 68-78.

[19] Lin, H., Kogan, M., Fischer, D. (1990) Induced Resistance in Soybean to the Mexican Bean Beetle (Coleoptera: Coccinelidae): Comparisons of Inducing Factors. Environmental Entomology, 19, 1852-1857. https://doi.org/10.1093/ee/19.6.1852

[20] Baldin, E.L.L. and Lara, F.M. (2001) Foliar Attractiveness and Consumption by Adults of Diabroticaspeciosa (Germ.) (Coleoptera: Chrysomelidae) in Different Genotypes of Pumpkin. Neotropical Entomology, 4, 675-679. https://doi.org/10.1590/S1519-566X2001000400024

[21] Baldin, E.L.L., Vendramim, J.D. and Lourenção, A.L. (2005) Resistance of Tomato Genotypes to Bemisiatabaci (Gennadius) Biotype B (Hemiptera: Aleyrodidae) in Tomato. Neotropical Entomology, 34, 435-441. https://doi.org/10.1590/S1519-566X2005000300012

[22] SAS-Institute (2002) SAS User's Manual, Version 9.1. SAS Institute, Cary, NC.

[23] Fenemore, P.G. (1980) Oviposition of Potato Tuber Moth, Phthorimaea operculella Zell. (Lepidoptera: Gelechiidae); Identification of Host-Plant Factors Influencing Oviposition Response. New Zealand Journal of Zoology, 7, 435-439. https://doi.org/10.1080/03014223.1980.10423798

[24] Baldin, E.L.L., Souza, D.R., Souza, E.S. and Beneduzzi, R.A. (2007) Control of the Whitefly with Plant Extracts, in Greenhouse Grown Tomato. Horticultura Brasileira, 25, 602-606. https://doi.org/10.1590/S0102-05362007000400022

[25] War, A.R., Paulraj, M.G., Ahmad, T., Buhroo, A.A., Hussain, B., Ignacimuthu, S. and Sharma, H.C. (2012) Mechanisms of Plant Defense against Insect Herbivores. Plant Signaling \& Behavior, 7, 1306-1320. https://doi.org/10.4161/psb.21663

[26] Kumar, S. and Saini, R.K. (2008) Feeding Preference and Damage Potential of $\mathrm{He}$ licoverpaarmigera (Hübner) on Different Promising Cotton Genotypes/Hybrid. Journal of Agricultural Science and Technology, 10, 411-420.

[27] Luong, T.T., Downes, S.J., Cribb, B., Perkins, L.E. and Zalucki, M.P. (2016) Oviposition Site Selection and Survival of Susceptible and Resistant Larvae of Helicoverpa armigera (Lepidoptera: Noctuidae) on Bt and Non-Bt Cotton. Bulletin Entomological Research, 106, 710-717. https://doi.org/10.1017/S0007485316000328

[28] Tabashnik, B.E., Rensburg, J.B.V. and Carrière Y. (2009) Field-Evolved Insect Re- 
sistance to Bt Crops: Definition, Theory, and Data. Journal of Economic Entomology, 102, 1-25. https://doi.org/10.1603/029.102.0601

[29] Peterson, J.A., Ode, P.J., Oliveira-Hofman, C. and Harwood, J.D. (2016) Integration of Plant Defense Traits with Biological Control of Arthropod Pests: Challenges and Opportunities. Frontiers in Plant Science, 7, 1-23. https://doi.org/10.3389/fpls.2016.01794

[30] Yamasaki, A. and Fujisaki, K. (2010) Larval Feeding Preference and Performance of the Cotton Bollworm, Helicoverpa armigera (Hübner) (Lepidoptera: Noctuidae), on Different Flower Parts of Cosmos. Applied Entomology and Zoology, 45, 627-633. https://doi.org/10.1303/aez.2010.627

[31] Baghery, F., Fathipour, Y. and Naseri, B. (2013) Nutritional Indices of Helicoverpaarmigera (Lep.: Noctuidae) on Seeds of Five Host Plants. Applied Entomology and Phytopathology, 80, 19-27.

[32] Browne, B. and Raubenheimer, D. (2003) Ontogenetic Changes in the Rate of Ingestion and Estimates of Food Consumption in Fourth and Fifth Instar Helicoverpaarmigera Caterpillars. Journal of Insect Physiology, 49, 63-71. https://doi.org/10.1016/S0022-1910(02)00247-0

[33] Wei, J., Guo, Y., Liang, G., Wu, K., Zhang, J., Tabashnik, B.E. and Li, X. (2015) Cross-Resistance and Interactions between Bt Toxins Cry1 Ac and Cry2Ab against the Cotton Bollworm. Scientific Reports, 5, 1-7. https://doi.org/10.1038/srep07714

[34] Rao, N.S. and Rao, P.A. (2008) Behavioural and Physiological Effects of Bt Cotton on Cotton Bollworm, Helicoverpaarmigera (Hub). Journal Entomology Research, 32, 273-278.

[35] Torres, J.B. and Ruberson, J.R. (2006) Spatial and Temporal Dynamics of Oviposition Behavior of Bollworm and Three of Its Predators in Bt and Non-Bt Cotton Fields. Entomologia Experimentalis et Applicata, 120, 11-22. https://doi.org/10.1111/j.1570-7458.2006.00422.x

[36] Greenplate, J.T., Mullins, J.W., Penn, S.R., Dahm, A., Reich, B.J., Osborn, J.A., Rahn, P.R., Ruschke, L. and Shappley, Z.W. (2003) Partial Characterization of Cotton Plants Expressing Two Toxin Proteins from Bacillus thuringiensis. Relative Toxin Contribution, Toxin Interaction, and Resistance Management. Journal of Applied Entomologic, 127, 340-347. https://doi.org/10.1046/j.1439-0418.2003.00766.x

[37] Tingle, F.C., Mitchell, E.R. and Heath, R.R. (1990) Preferences of Mated Heliothis virescens and Subflexa Females for Host and Nonhost Volatiles in a Flight Tunnel. Journal of Chemical Ecology, 16, 2889-2898. https://doi.org/10.1007/BF00979481

[38] Ramaswamy, S.B., Keung Ma, W. and Baker, G.T. (1978) Sensory Cues and Receptors for Oviposition by Heliothis virescens. Entomologia Experimentalis et Applicata, 43, 159-168. https://doi.org/10.1111/j.1570-7458.1987.tb03600.x

[39] Jallow, M.F.A., Zalucki, M.P. and Fitt, G.P. (1999) Role of Chemical Cues from Cotton in Mediating Host Selection and Oviposition Behaviour in Helicoverpa armigera (Hübner) (Lepidoptera: Noctuidae). Australian Journal of Entomology, 38, 359-366. https://doi.org/10.1046/j.1440-6055.1999.00131.x

[40] Yan, F., Bengtsson, M., Anderson, P., Ansebo, L., Xu, C. and Witzgall, P. (2004) Antennal Response of Cotton Bollworm (Heliocoverpa armigera) to Volatiles in Transgenic Bt Cotton. Journal of Applied Entomology, 128, 354-357. https://doi.org/10.1111/j.1439-0418.2004.00857.x

[41] Naseri, B., Fathipour, Y., Moharramipour, S. and Hosseininaveh, V. (2009) Comparative Life History and Fecundity of Helicoverpa armigera (Hubner) (Lepidopte- 
ra: Noctuidae) on Different Soybean Varieties. Entomological Science, 12, 147-154. https://doi.org/10.1111/j.1479-8298.2009.00310.x

[42] Olsen, K.M. and Daly, J.C. (2000) Plant-Toxin Interactions in Transgenic Bt Cotton and their Effect on Mortality of $<\mathrm{I}>$ Helicoverpa armigera $</$ I $>$ (Lepidoptera: Noctuidae). Journal of Economic Entomology, 93, 1293-1299.

https://doi.org/10.1603/0022-0493-93.4.1293

[43] Zitsanza, E.S., Giga, D.P. and Knight, J.D. (2006) Oviposition Site Preferences by Helicoverpa armigera (Lepidoptera: Noctuidae): Effect of Season and Density on Distribution of Eggs on Plants. South African Journal of Plant and Soil, 23, 138-141. https://doi.org/10.1080/02571862.2006.10634744

[44] Jongsma, M.A., Gould, F., Legros, M., Yang, L., Van Loon, J.J.A. and Dicke, M. (2010) Insect Oviposition Behavior Affects the Evolution of Adaptation to Bt Crops: Consequences for Refuge Policies. Evolutionary Ecology, 24, 1017-1030. https://doi.org/10.1080/02571862.2006.10634744

[45] Gore, J., Leonard, B.R. and Jones, R.H. (2003) Influence of Agronomic Hosts on the Susceptibility of Helicoverpa zea (Boddie) (Lepidoptera: Noctuidae) to Genetically Engineered and Non-Engineered Cottons. Environmental Entomology, 32, 103-110. https://doi.org/10.1603/0046-225X-32.1.103 


\section{Appendix}

Table S1. Description of soybean cultivars used for the study of preference of Helicoverpa armigera.

\begin{tabular}{|c|c|c|c|c|}
\hline Cultivar & $\begin{array}{c}\text { Genetic Transformation } \\
\text { Event }\end{array}$ & $\begin{array}{l}\text { Common } \\
\text { Name }\end{array}$ & Scientific Name & $\mathrm{N}^{\circ}$ Record \\
\hline TMG 2183IPRO & MON $87701 \times 89788$ & Soybean & $\begin{array}{l}\text { Glycinemax (L.) } \\
\text { Merr. }\end{array}$ & 28,139 \\
\hline M 8210 IPRO & MON $87701 \times 89788$ & Soybean & $\begin{array}{l}\text { Glycinemax (L.) } \\
\text { Merr. }\end{array}$ & 28,137 \\
\hline M 8644 IPRO & MON 87701 × 89788 & Soybean & $\begin{array}{c}\text { Glycinemax (L.) } \\
\text { Merr. }\end{array}$ & 31,180 \\
\hline M 8372 IPRO & MON $87701 \times 89788$ & Soybean & $\begin{array}{l}\text { Glycinemax (L.) } \\
\text { Merr. }\end{array}$ & 31,185 \\
\hline AS 3820 IPRO & MON $87701 \times 89788$ & Soybean & $\begin{array}{l}\text { Glycinemax (L.) } \\
\text { Merr. }\end{array}$ & 29,751 \\
\hline M 8330 IPRO & MON $87701 \times 89788$ & Soybean & $\begin{array}{l}\text { Glycinemax (L.) } \\
\text { Merr. }\end{array}$ & 29,690 \\
\hline HK 8314 IPRO & MON $87701 \times 89788$ & Soybean & $\begin{array}{c}\text { Glycinemax (L.) } \\
\text { Merr. }\end{array}$ & 32,208 \\
\hline HK 8514 IPRO & MON $87701 \times 89788$ & Soybean & $\begin{array}{c}\text { Glycinemax (L.) } \\
\text { Merr. }\end{array}$ & 32,207 \\
\hline M 9144 RR & GTS-40-3-2 & Soybean & $\begin{array}{c}\text { Glycinemax (L.) } \\
\text { Merr. }\end{array}$ & 19,393 \\
\hline FTS CAMPO NOVORR & GTS-40-3-2 & Soybean & $\begin{array}{c}\text { Glycinemax (L.) } \\
\text { Merr. }\end{array}$ & 27,083 \\
\hline FTS PARAGOMINAS RR & GTS-40-3-2 & Soybean & $\begin{array}{c}\text { Glycinemax (L.) } \\
\text { Merr. }\end{array}$ & 29,772 \\
\hline M-SOY 9350 & Convencional & Soybean & $\begin{array}{l}\text { Glycinemax (L.) } \\
\text { Merr. }\end{array}$ & 02,675 \\
\hline
\end{tabular}

Fonte: $\mathrm{CTNBIO}=$

http://ctnbio.mcti.gov.br/liberacao-comercial///document_library_display/SqhWdohU4BvU/view/678023? _110_INSTANCE_SqhWdohU4BvU_redirect=http\%3A\%2F\%2Fctnbio.mcti.gov.br\%2Fliberacao-comercial

\section{Scientific Research Publishing}

\section{Submit or recommend next manuscript to SCIRP and we will provide best} service for you:

Accepting pre-submission inquiries through Email, Facebook, LinkedIn, Twitter, etc. A wide selection of journals (inclusive of 9 subjects, more than 200 journals)

Providing 24-hour high-quality service

User-friendly online submission system

Fair and swift peer-review system

Efficient typesetting and proofreading procedure

Display of the result of downloads and visits, as well as the number of cited articles

Maximum dissemination of your research work

Submit your manuscript at: http://papersubmission.scirp.org/

Or contact ajps@scirp.org 